UDK 73.033.4(497.5 Split)

Izvorni znanstveni rad

Primljeno 8. svibnja 2020.

DOI: $10.38003 /$ zrffs.13.4

Daniela Matetić Poljak

Sveučilište u Splitu, Umjetnička akademija

HR-21000 Split, Fausta Vrančića 17a

daniela.matetic-poljak@umas.hr

\title{
PRILOG JEDNOJ KIPARSKOJ RANOROMANIČKOJ RADIONICI U SPLITU
}

\begin{abstract}
Sažetak
U članku je provedena stilska i ikonografska analiza konzole s prikazom lava koja je kao spolij bila ugrađena na zabatu kuće Mangjer u Splitu. Kuća se nalazila na križanju Manđerove i Bribirske ulice. Nakon njezina rušenja, konzola je prenesena u Samostan sestara milosrdnica svetog Vinka Paulskog u Splitu, gdje se i danas čuva. Izvorni arhitektonski kontekst konzole nije poznat. Tipski i stilski srodan joj je par konzola na portalu crkve svetog Mikule (sv. Nikole) u Velom Varošu u Splitu. Autorica ih grupira u krug iste ranoromaničke radionice koja je djelovala koncem 11. i početkom 12. stoljeća. Konzola s kuće Mangjer nastaje nedugo nakon para konzola sa Svetog Mikule. Izradio ju je majstor koji dobro poznaje potonje konzole, vješto kopira njihovu kompoziciju i dimenzije. U oblikovanju zahtjevnijih dijelova (poput lavlje glave ili akantusova lista na konzolici pod lavljom figurom) otkriva nešto slabiji oblikovni kapacitet u odnosu na predložak.
\end{abstract}

Ključne riječi: arhitektonska skulptura, ranoromanička radionica, Split, lav, ikonografija

\section{Uvod}

Prve naznake romaničkog stila razaznaju se na djelima splitskih klesarskih radionica tijekom druge polovice 11 . stoljeća. Nova stilska stremljenja razabiru se na crkvenom namještaju u plastičnijem oblikovanju motivâ predromaničkoga korpusa, obogaćivanju toga korpusa novim vegetabilnim shemama, uvođenju ljudskog lika. ${ }^{1}$ Novost predstavlja i afirmacija arhitektonske figurativne skulpture, čiji razvitak započinje uoči kraja stoljeća.

Navedene značajke uklapaju se u opće pravce kojima se razvija skulptura na zapadu tijekom 11. i u prvoj četvrtini 12. stoljeća. Arhitektonska skulptura doživljava procvat, a princip eksteriornosti zamjetan u oblikovanju crkvenog zdanja, aplicira skulpturu na vanjskom oplošju zidova, prije svega na pročeljima (frons), na kojima portal, sukladno simboličkoj topografiji, postaje glavni nositelj sadržaja na vizualnoj i ikonografskoj razini (Jurković 1992; Goss 2012). Sve izraženiji

1 O ranoromaničkim skulpturama i radionicama u Splitu, Prijatelj 1954; Petricioli 1960; Petricioli 1983: 24-25; Burić 1992; Petricioli 1993; Burić 2002; Piteša 2007. O reljefu s prikazom vladara iz splitske krstionice iscrpnu bibliografiju donosi Fisković 2002. Nakon njega reljefom se pozabavio Babić 2010. 
plasticitet skulpturâ postaje važan element monumentalizacije crkvenih pročelja. U ikonografskom pogledu, zamjetno je s jedne strane razvijanje narativnih shema, a s druge polisemantičkog sadržaja pojedinih prikaza i figura (čije preciznije značenje dijelom određuje njihova topografska pozicija na građevini, kao i mjesto u općem ikonografskom kontekstu).

Mijene u domeni skulpture (koje predstavljaju tek segment sveukupnih promjena koje donosi rana romanika) zbivaju se u vremenskom okviru kojemu pečat daje crkveni reformski pokret, koji u zadaći učvršćivanja crkvene hijerarhije, neovisnosti i obnove Crkve, proklamira povratak prvotnim kršćanskim vrijednostima.

Razvijanje figurativnosti, revival pojedinih ranokršćanskih ikonografskih tema, narativnost ikonografije (i slikarskih i kiparskih djela), kao i sve izraženiji skulpturalni plasticitet tijekom 11. stoljeća, predstavlja se većinom kao vizualni ekvivalent proklamiranog povratka prvotnim kršćanskim vrijednostima koji se očituje u proučavanju i nadahnjivanju ranokršćanskom umjetnošću. No, rana romanika podjednako „otkriva“ i motive korpusa antičke arhitektonske dekoracije, kao i bizantske elemente i ikonografske sheme. 0 pitanju kakvu su ulogu i u kojoj mjeri u širenju diljem zapada odigrale pape, papinski legati, biskupi, glavari samostana, zadužbinari, te treba li se taj renovatio gledati kao zasebni povijesno-umjetnički fenomen, ili kao tek jedan od niza ranokršćanskih renovatia srednjovjekovne umjetnosti na zapadu, ne postoji jedinstven stav. Istraživanje pojedinačnih spomenika tog razdoblja, njihovo sagledavanje u mikroregionalnom okruženju, dopunjavanje spoznaja analizom pojedinačnih primjera u svrhu otkrivanja šire slike, postavlja se kao preduvjet za traženje odgovora na tu dilemu. ${ }^{2}$

Proučavanje svakog spomenika na kojem se uočavaju nova strujanja u kontekstu splitske baštine, predstavlja važan korak u sagledavanju razvitka novog stila i u domeni likovnosti i u društveno-povijesnom okviru.

Korpus splitske romaničke arhitektonske skulpture čine većinom spoliji ugrađeni na kućama u široj povijesnoj gradskoj jezgri, ${ }^{3}$ pokoji element pronađen tijekom arheoloških istraživanja te skulpture sa splitskog zvonika. Budući da niti jedno izvorno romaničko crkveno pročelje nije sačuvano, kao ni ranoromanički zvonici (uz iznimku zvonika sv. Teodora na kojem nema tragova figurativne arhitektonske skulpture), te da je reprezentativnija svjetovna arhitektura (na kojoj je takva skulptura bila moguća) preoblikovana ili rastočena kasnijim gradnjama i dogradnjama, izvorni kontekst većine djela nije poznat. Budući da je liniju romaničke splitske skulpture iz navedenih razloga teško pratiti, svaka mogućnost prepoznavanja i objedinjavanja djela oko pojedinih radionica predstavlja važan doprinos proučavanju teme.

Konzola s prikazom lava, koja se danas čuva u Samostanu sestara milosrdnica

2 O utjecaju reformi na pojavu ranoromaničke umjetnosti i njezinim karakteristikama na istočnoj obali Jadrana vidi Jurković 1992; Goss 2012; Jurković 2016. O utjecaju crkvenoga reformskog pokreta tijekom 11. i u prvoj četvrtini 12. stoljeća na razvitak ranoromaničke umjetnosti u Europi vidi Franzé 2015: 1-14, koja donosi povijest proučavanja problematike s pregledom najvažnije literature. Rousso 2008, proučava utjecaj reformskih ideja na uvođenje skulpturalne figuracije. Argumente pro et contra teorije o sustavno osmišljenom i provedenom programu reforme koji obuhvaća i likovnost (svojevrsnom dictusu papae koji se odnosi na prikaze) sažimaju Quintavalle 2015 (koji iznosi pledoaje toj teoriji) i Barall i Altet: 2015, koji upozorava na problematičnost te teorije u pojašnjavanju širenja novog stila diljem zapada.

3 Cvito Fisković zaslužan je za objavljivanje većine spolija, Fisković 1940; Fisković 1952; Fisković 1981. 
sv. Vinka Paulskog u Splitu, predstavlja vrijedno djelo arhitektonske figurativne skulpture. Konzola je kao spolij bila ugrađena na kući Mangjer, koja se nalazila na uglu Manđerove i Bribirske ulice. Nakon njezina rušenja sredinom devedesetih godina prošlog stoljeća, konzola se čuva u Samostanu (Slika 1).

Premda je njezinu fotografiju bez podrobnije analize objavio Fisković, ovo djelo začudo nije pobudilo veći interes (Fisković 1979: 305, sl. 8.). Tijekom 2018. godine konzola je pod vodstvom profesora Ive Donellija restaurirana na Odsjeku konzervacije-restauracije Umjetničke akademije u Splitu, što je bila prigoda za njezino podrobnije proučavanje.

Nakon detaljnog opisa i formalno-stilske analize u članku će biti provedena komparacija sa srodnim skulpturama, predložena datacija, provedena ikonografska analiza te određeno mjesto i važnost u korpusu splitske romaničke skulpture.

\section{Formalno-stilska analiza}

Za izradu konzole (vapnenac, v. $34 \mathrm{~cm}$, d. $54 \mathrm{~cm}$, dužina vidljivog dijela konzole 27 $\mathrm{cm}$, s. $16 \mathrm{~cm}$; d. konzolice $22 \mathrm{~cm}$; š. konzolice $16 \mathrm{~cm}$ ) reutiliziran je antički ulomak. $\mathrm{U}$ širini tog elementa isklesana je frontalna strana konzole, dok su njegova prednja i stražnja stranica, postale bočne stranice konzole priklesane u trapezoidnoj formi. Na bočnim stranicama jasno se razlikuje dio koji je bio umetnut u zidnu masu, na kojem je sačuvana izvorna profilacija antičkog ulomka (dvije trake različite širine koje se spajaju pod pravim kutom uokvirujući izdubljenu površinu), od dijela koji je bio vidljiv izvan zidne mase.

Lavlja figura prikazana je u sjedećem položaju, postavljena na malenu konzolu (u daljnjem tekstu konzolica). S gornje i stražnje strane figure izrađen je okvir u obliku obrnutog slova L, artikuliran jednostavnom profilacijom, sastavljenom od tanke trake, užljebom odijeljene od S profila (koji podsjeća na plastički reduciranu cymu reversu). Trokutasti prostor između figure i okvira je perforiran (Slika 2).

Glava je oblikovana poput mačje. Malene ušne školjke, zakrenute postrance, stilizirane su u obliku uglate spirale. „Čitljivost" detalja obrade lica umanjuje erozija materijala. Na glavi se ističu širom otvorene bademaste oči pojednostavnjene modulacije (blago ispupčenoga gornjega kapka, linijom urezanim donjim kapkom, udubljenih kružnih zjenica). Nad urezanim lučnim obrvama, uzdiže se glatko čelo i glatka kalota glave. Zbog oštećenja njuške, razaznaje se tek tanak korijen nosa i dva udubljenja koja predstavljaju ostatke nozdrva. Zanimljiva je stilizacija usta: u uglovima usana nalaze se udubljenja, sredina usta naznačena je kružnicom udubljenog središta, a između nje i uglova usana alterniraju se udubljenja i ispupčenja koja su predstavljala zube. Lav je očigledno bio prikazan s iskešenim zubima, no zbog erozije kružno udubljenje po sredini usta danas licu daje određenu ljupkost. Nad usnama su bili oblikovani brkovi, no nije moguće iščitati detalje njihove izvedbe. Vrat je obuhvaćen ogrlicom sastavljenom od dvaju tankih obruča. Blago je ukošena pa izgleda kao da je njome lav privezan uz gornju stranicu okvira konzole. Griva - važan atribut koji ovu skulpturu vizualno označava lavljom - prekriva dio vrata ispod ogrlice, ramena i gornji dio leđa. Izrađena je u pramenovima čija stilizacija podsjeća na oblik kukâ na oltarnim ogradama iz druge polovice 11. stoljeća (Belamarić 1991; Petricioli 1993; Rapanić 1997: slika na stranici 298; Piteša 2007, sl. 1. i 3.). Pramenovi su izvedeni plitkim urezima (Slika 3). 
Grudni koš naglašenog je volumena, ponešto povelik u odnosu na tijelo. Prednjim tankim, valjkastim nogama, lav se upire o pulvin konzolice. Prsti na šapama odijeljeni su urezima. Stražnje noge su savijene i slabije razvijene od ostatka tijela. Plošne su obrade. Prate zakrivljenost konzolice. Rep životinje pojavljuje se između stražnjih nogu, obavija polovicu struka na bočnoj stranici figure te završava zadebljanjem (pojednostavnjenom stilizacijom anatomskog čuperka repa ) položenim po sredini leđa.

$\mathrm{Na}$ desnoj stranici konzole, iza vertikalne profilacije okvira, identitet životinje potvrđen je vertikalnim natpisom LEON, izvedenim kapitalom.

Konzolica pod figurom lava pripada S tipu konzole s jednom volutom. Pulvin je gladak (prednja strana volutina svitka), obuhvaćen po sredini dvama prstenovima. Voluta završava glatkim plosnatim okulusom. Na donjoj stranici konzolice isklesan je akantusov list građen od širokoga središnjeg rebra, koji nadvisuje povijeni, plosnati vršak i dva para režnjeva (gornji sastavljen od dvaju listića, donji reduciran na jedan). Fond između akantusova lista i bočnih bridova stranice ispunjen je s po jednim ukošenim listićem. Glatka trokutasta forma odvaja ga od lista (Slika 4a).

\section{Srodni primjerci}

Par konzola koje podržavaju trokutasti zabat portala crkve sv. Mikule u Velom Varošu predstavlja bliske srodnike konzoli s kuće Mangjer. Premda ove konzole predstavljaju vrijedne spomenike, neizostavne u pregledima razvitka romaničke skulpture u Dalmaciji, zanimljivo je to da one do sada nisu detaljno opisane, niti podrobnije analizirane (Slika 5) (Fisković 1949; Belamarić 1990: 50; Fisković 2000: 642; Belamarić 2001: 20.).

Konzole su izrađene od vapnenca (v. $32 \mathrm{~cm}$, d. bočne stranice $34 \mathrm{~cm}$, š. $18 \mathrm{~cm}$; d. konzolice $20 \mathrm{~cm}$, š. 17,5 cm). Prikaz i obrada detalja obiju konzola identični su, a jedinu razliku predstavlja zrcalna orijentacija lavlje figure na njihovim bočnim vanjskim stranicama.

Tipski i kompozicijski ove konzole odgovaraju konzoli s Mangjerove kuće: ista je postavka lavlje figure, tip konzolice pod njom, tip okvira. Razlike se otkrivaju u oblikovanju pojedinih dijelova i detalja. Općenito uzevši, na paru konzola tektonika formi je čvršća, izvedba kvalitetnija (Slika 6).

Lavlja glava je voluminoznija i šira. Unatoč eroziji kamena, vidljivo je da su očni kapci plastičnije definirani nego na konzoli s kuće Mangjer. Oči su imale udubljene zjenice koje se danas jedva primjećuju. Čelo iznad obrva je nabrano. Trokutaste, blago zaobljene uši, okrenute su en face, a unutrašnjost ušne školjke je glatka, obrubljena tankim kružnim urezom. Nos je tanak. Usta su blago otvorena. Sferična udubljenja u njihovim uglovima, obrubljena tankim urezom, zatvaraju iskešeni oštri očnjaci koji glavi daju ponešto zastrašujući izraz (Slika 7).

Griva koja prekriva vrat pod ogrlicom, simetrično se spušta s obiju strana grudnog koša. Svaki njezin pramen uvija se prema leđima. Artikuliran je jednim ili dvama urezima i završava sitnim kružnim ispupčenjima. Kod konzole s kuće Mangjer pramenovi se uvijaju u suprotnom smjeru, plosnatije su izvedbe, stilizacijom podsjećaju na kuke s oltarnih ograda (Slika 8).

Na paru konzola prostor koji omeđuju stranice okvira i leđa lava predstavlja glatki fond, na kojem je, na vanjskoj bočnoj stranici, oblikovan dugački rep naglašenog 
čuperka. Na konzoli s kuće Mangjer taj prostor je perforiran, a rep slične stilizacije položen na leđima lava.

Profilacija okvira na paru konzola jednostavnija je: horizontalna stranica podijeljena je u tri trake nejednake širine, vertikalna na dvije. Vizualno je čitljivija i strukturaliziranija od profilacije na konzoli s kuće Mangjer.

U izvedbi konzolice pod lavom također postoje razlike. Na paru konzola presjek konzolice upisuje se u pravokutnik. Tijelo volute gotovo je vodoravno. Predstavlja traku koja se pod pravim kutom spaja s trakom na vertikalnoj stranici okvira. Sužavajući se, spaja se s okulusom. Pulvin je voluminozniji. List apliciran na donjoj strani gotovo je vodoravan. Građen je od plosnatog rebra, obrubljenog tankim urezom, koje se lagano širi prema vrhu i završava presavijenim plosnatim vrškom. S obiju strana rebra superponiraju se tri para listića postavljena na V. Gornji par lagano se svija prema dolje. Listići su različite dužine (donji par je najduži). Po sredini su artikulirani nervaturom. Struktura i stilizacija lista otkriva određeni stupanj inspiracije kasnoantičkim predlošcima. ${ }^{4}$ Između bočnog brida konzolice i lista akantusa ubačen je po jedan ukošeni listić. Shema i izvedba akantusova lista pokazuje koherentniju strukturu od lista s Mangjerove konzole (Slika 4b).

Pišući o portalu Svetog Mikule, Fisković je zamijetio sličnost stilizacije listova s para konzola i listova na donjem vijencu kapitela kod stupova u unutrašnjosti crkve. Valja primijetiti da je akantusov list s Mangjerove konzole obradom bliži lišću s tih kapitela nego list na paru konzola (Slika 9).

Do obnove crkve svetog Mikule 1949. godine po jedna konzola stajala je na uglovima baroknog pročelja crkve (Slika 10 i Slika 11).

Tijekom obnove barokno je pročelje porušeno, a crkva vraćena na ranoromaničke gabarite. ${ }^{5}$ Tom prilikom izvedena je idejna rekompozicija portala $u$ formi jednostavnoga zabatnog portala (protirona) čije bočne stranice podržava par konzola. ${ }^{6}$ Između njih postavljen je mramorni nadvratnik s natpisom donatora Johannesa i žene mu Tihe. Prema navodu C. Fiskovića, pri rekompoziciji portala konzervatori su se poveli za primjerom portala na crkvi svetog Petra u Supetarskoj Drazi na otoku Rabu, na kojem se, do prije nekoliko godina, nalazio par konzola s figurom grifona (Fisković 1949: 215). Taj se portal u vrijeme konzervatorskih radova na Svetom Mikuli smatrao koherentnim djelom iz druge polovice 11. stoljeća. Kasnija su istraživanja pomaknula dataciju portala u drugu polovicu 12. stoljeća. Konzole s grifonima (koje poput para konzola na Svetom Mikuli imaju s gornje strane horizontalnu stranicu okvira) podržavale su luk unutar zabata portala. Zbog predubokog umetanja u zidnu masu i nepodudaranja dimenzija prihvatne plohe horizontalne stranice okvira i ležajne plohe luka nad njim, Ilić Olujić dovela

4 Acanthus spinosus reduciranog plasticiteta, sa širokim središnjim rebrom, plosnatim povijenim vrškom, nervaturama koje prolaze sredinom listića, u različitim je stilizacijama apliciran na kapitelima maloazijske (poglavito prokoneške) produkcije od kraja 3. do 5. stoljeća. Ti se produkti učestalo izvoze diljem Sredozemlja. Njihove tipološke i stilske varijacije donose Kautzsch 1936, Pensabene 1993 i Pensabene 2015. Primjere lokalne produkcije 5. i 6. stoljeća, koja se nadahnjuje pojedinim stilizacijama listova, no daje slobodniju interpretaciju njihove strukture, donosi Matetić Poljak 2017: 391-392, sl. 4 E, F.

5 Fisković 1949: 219, iznosi pretpostavku da se barokno proširenje crkve dogodilo koncem 17. stoljeća.

6 Ta se forma portala u hrvatskoj znanstvenoj bibliografiji naziva i formom reduciranoga lombardskog protirona, Belamarić 2001: 50. 
je u pitanje njihovu izvornu pripadnost toj fazi. Autorica drži da je portal iz druge polovice 12. stoljeća bio lišen elemenata figuracije. Prema tipskim odlikama dovodi ga u vezu sa zreloromaničkim portalima Svetog Krševana u Zadru, katedrale u Krku i katedrale svete Marije u Rabu, datiranim također u drugu polovicu 12. stoljeća. Šrenje tog tipa zabatnog portala povezuje s teritorijem Zadarske nadbiskupije i njezinim utjecajem na sufraganske biskupije (Ilić Olujić 2007).

Ilić Olujić, doduše, otvara mogućnost izvorne pripadnosti konzola s grifonima ranijoj fazi pročelja i ranoromaničkom portalu. Uzimajući kao argument činjenicu da glave grifonâ gledaju prema naprijed, dok na talijanskim primjerima životinje koje flankiraju otvore (portale ili prozore) učestalo imaju glave blago okrenute prema otvoru, iznosi tezu o njihovoj mogućoj drukčijoj izvornoj poziciji na crkvi ili na zvoniku sagrađenom pored nje. Iz istog razloga izražava sumnju u izvornu poziciju lavljih konzola na portalu Svetog Mikule.

Mišljenja sam da zakrenutost glava životinja na konzolama ne bi trebalo uzdizati na razinu argumenta kojim se brani ili osporava njihova pozicija na portalima. Što se tiče para konzola sa Svetog Mikule, zrcalan prikaz lavljeg repa na bočnim vanjskim stranicama konzola, potvrđuje da su one u paru flankirale neki otvor na crkvi. U konkretnom slučaju to je mogao biti jedino portal.

\section{Datacija}

Par konzola sa Svetog Mikule i konzolu s kuće Mangjer povezao je C. Fisković objavivši njihove fotografije jednu pored druge (Fisković 1979). No, on se nije upuštao u podrobniju analizu njihovih odnosa.

Konzole sa Svetog Mikule djelo su kvalitetne radionice. Stilizacija lavlje glave otkriva stupanj sličnosti s apulijskim primjerom stilizacije lavlje glave na štioniku propovjedaonice majstora Acceptusa (datiranog natpisom u 1041. godinu), koja je pohranjena u Museo Lapidario di Sanctuario di S. Michele archangelo u Monte Sant'Angelu (Belli D’Ellia 1987: 39; Belli D’Ellia 2003: 47-48, sl. 25). Premda je riječ o malim dimenzijama, poluotvorena usta, oblikovanje brkova, nosa, širom otvorenih očiju, obrva i naboranog čela, jasno upućuju na to da je splitski majstor poznavao srodne predloške koji su cirkulirali u toj pokrajni. ${ }^{7}$

Datacija para konzola sa Svetog Mikule polazište je za dataciju konzole s kuće Mangjer.

O vremenu gradnje i slijedu intervencija na crkvi svetog Mikule razvilo se nekoliko teorija koje se, uz tipološku arhitektonsku analizu, stilsku analizu kapitela i oltarne ograde, uz epigrafsku analizu natpisa na crkvi, oslanjaju i na interpretaciju povijesnih podatka o donatorima crkve: supružnicima Johannesu i Tihi te Nemiri Messagalini. ${ }^{8}$ Potonja se spominje u darovnici dopisanoj na listini o osnutku samostana svetog Benedikta iz 1068. godine, u kojoj se navodi da je ona gradila crkvu svetog Nikole koju

7 Valja podsjetiti na još jedan ustanovljen utjecaj ranoromaničkih apulijskih stilizacija lavljih glava na splitske skulpture, Flèche Mourges i sur. 1993: 268; Piteša 2012: 64. Riječ je o reljefu s ranoromaničkog ambona splitske katedrale (iz 12. stoljeća) i vodorige u obliku lavlje glave, reutilizirane na pročelju hotela Central, čija je stilizacija bliska stilizaciji lavljih glava na jednom kapitelu iz kripte katedrale u Otrantu (datiranom u treću četvrtinu iz 11. stoljeća). Kapitel je objavila Belli d’Ellia 1987: 17.

8 Konzole se u tom kontekstu spominju tek kao ranoromanička djela. 
poklanja samostanu. ${ }^{9}$ Ime supružnika Johannesa i Tihe spominje se na mramornom nadvratniku portala Svetog Mikule, ${ }^{10}$ a Johannesovo ime zapisano je i na trabeaciji oltarne ograde (na natpisu koji se poziva na natpis na portalu, u kojem se precizira da je crkvu sagradio s drugom ženom, ali imovinom prve) ${ }^{11}$ Zbog uništenog dijela natpisa koji slijedi na trabeaciji, postoje različiti prijedlozi njegove restitucije, koji posredno utječu i na samo datiranje gradnje crkve. ${ }^{12}$ Bez ulaženja u detalje, osvrnut ću se na slijed tih prijedloga koji su posljedično utjecali na identificiranje donatora. Prema Katićevoj restituciji, koju donosi Fisković, na natpisu se spominje i nezakonit porod s kojim gradi crkvu i djeca koja, nakon Johannesove smrti, dovršavaju gradnju, ${ }^{13}$ dok prema Kravarovoj, crkvu nakon Johannesove smrti grade njegove sestre. $^{14}$

Datacija crkve, mogućih faza gradnje i intervencija na njoj, kao i angažmana navedenih donatora u pojedinim fazama, nije općeprihvaćena. Fisković crkvu drži djelom domaćih majstora koji povezuju predromanički i romanički stil. Smatra da crkvu podižu Johannes i njegova žena u prvoj polovici 12. stoljeća. Lavlje konzole i kapitele u unutrašnjosti crkve vidi kao djelo iste radionice, dok za ulomke trabeacije oltarne ograde drži da su nastali nakon njih. Odlučno odbija mogućnost povezivanja crkve koja se spominje u darovnici Nemire Messagaline s crkvom svetog Mikule (Fisković 1949: 218). Jakić-Cestarić, kao što je spomenuto, prihvaća identifikaciju crkve svetog Mikule s crkvom koja se navodi u darovnici Nemire Messagaline, no želeći zadržati Fiskovićevu dataciju crkve u 12. stoljeće, nastanak darovnice pomiče

9 CD I, 112. Isprava o osnivanju samostana datira se 1068. godine (u izdanjima Codex Diplomaticusa koja su priredili Rački i Kukuljević datirana je 1069. godine). Crkvu iz Nemirine u darovnici sa Svetim Mikulom prvi povezuju Jelić, Bulić, Rutar 1894: 213.

10 Natpis s nadvratnika glasi:

+STATVIT HOC TEMPVUM CHR(IST)I DE MUNERE CELSUM

ILLVSTRIS CLARVS D(OMI)NO DONANTE IONANNES

CONIVGE CUM TICHA PRIMAM POST ALTERA DUCTA

SCRIPTA SIT LAVS RARA...IE SERENA HIS REQEM POSCAT PLEBIS I...OSC

U Baradinom prijevodu (Barada 1952: 182):

„Pomoću Kristovom sagradi ovaj uzvišeni hram,

darom Gospodnjim znameniti, slavni Ivan

sa ženom Tihom, koju drugu poslije prve oženi.

Neka je zapisana slava izvrsna..."

11 Transkripcija prema Delonga 1997: 21:

+ HANC DOMV(m) VT IN SVPERIORI LIMINE HABETVR IOH(anne)S

CV(m) SECVNDA VXORE C(on)QVESTV PRI [me]E SED MORTE P(rae) VEN[ta]

CV(m) SVI(s) SORORIB(vs) STA[tvit...]

Prijevod koji donosi Delonga: „Ovu kuću (sc. crkvu), kako na gornjem pragu piše, Ivan sa drugom ženom, ali imovinom prve, koju smrt preteče, sa svojim sestrama sagradi...”

12 Pregled problematike restitucije teksta i njegova čitanja donose Jakić-Cestarić 1980: 179 i Rapanić 1997. Barada 1952: 181-182, prevodi samo čitljivi dio teksta ne ulazeći u restituciju dijela koji nedostaje. Smatra da prema oblikovnim karakteristikama slova i formulacijama teksta natpis nastaje koncem 11. i početkom 12. stoljeća.

13 Prema Katićevu prijedlogu restitucije tog dijela natpisa: „ cumque stupri sobole coepit sed morte preventus non perfecit....N. N. (vjerojatno Ivanov sin) cum suis sororibus Stana et ....(druga Ivanova kći) perfecit opus“, Fisković 1949: 216.

14 Kravar predlaže: „cumque stupri [sobol]e, sed morte pr[ae]ven[tus]........ cum sui[s] sororibu[s] sta[tuit]“. Jakić-Cestarić 1980: 179 naglašava da su prema toj restituciji crkvu nakon Johannesove smrti nastavile graditi njegove sestre i u tom je pothvatu sudjelovao još netko, čiji se spomen nalazi na otučenom dijelu natpisa. 
u razdoblje posljednjih petnaest godina 11. stoljeća. Donatora Johannesa povezuje s Johannesom Messagalinom, koji se u svojstvu svjedoka navodi u ispravi kojom nadbiskup Lovro, prigodom osnutka samostana sv. Benedikta, poklanja samostanu neke zemlje i crkvu sv. Marije. ${ }^{15}$ Prva prepoznaje rodbinski odnos brata i sestre između Nemire i Johannesa Messagaline. Početak gradnje, koju pripisuje Johannesu i njegovoj ženi, smješta u devedesete godine 11. stoljeća, a njezin dovršetak početkom 12. stoljeća pripisuje Johannesovim nasljednicima i sestrama. Što se tiče natpisa na portalu, mišljenja je da su ga nakon Johannesove smrti koncem 11. stoljeća postavili njegovi nasljednici, a izradu trabeacije oltarne ograde pripisuje drugoj generaciji Johannesovih nasljednika (primiceriusu Masiusu i bratu mu Iohannesu, koje spominje Toma Arhiđakon u vezi s jednim događajem iz 1136. godine). Smatra da se njihova intervencija zbila ranije spomenute godine (Jakić-Cestarić 1980: 182-183). Marasović prema tipološkim i oblikovnim arhitektonskim odlikama razlikuje dvije faze gradnje crkve: predromaničku i romaničku. Predromaničku fazu povezuje s Nemirom Messagalinom i samom gradnjom crkve, koju datira oko 1068. godine (pribrojivši toj fazi oblikovanje stupova s kapitelima u interijeru, izradu prve faze oltarne ograde). Romaničku fazu povezuje s donatorima Johannesom Messagalinom i Tihom, obnovom crkve koncem 11. i početkom 12. stoljeća koja je obuhvatila gradnju portala, zamjenu kupole tornjem i izradu oltarne ograde. Za potonju precizira da je podignuta nakon portala (Marasović 1994: 214-215; Marasović 2011: 362). Dvije faze odjeljuje i Goss: u arhitektonskom pogledu klasificira crkvu kao predromaničku, datirajući je u drugu polovicu 11. stoljeća, dok portal s konzolama lavova i oltarnu ogradu (koju vezuje za Johannesovu obnovu) pribraja romaničkom stilu i datira je u 12. stoljeće (Goss 1987: 142-143). ${ }^{16}$ Nasuprot navedenim mišljenjima, Delonga crkvu smatra ranoromaničkom. Prema njezinu mišljenju gradnju započinje Johannes Messagalina sa ženom, a dovršava je njegova sestra Nemira. Oba natpisa datira krajem 11. i početkom 12. stoljeća (Delonga 1997: 5, 19, 21). Isto mišljenje dijeli i Rapanić koji drži da je crkva suvremena natpisu na portalu (Rapanić 1997: 333). Ranoromaničkom crkvu smatra i Jurković (Jurković 1992: 205; Jurković 1996: 334). U novijem članku pojašnjava da je crkva, koja se spominje u Nemirinoj darovnici, remodelirana krajem 11. i početkom 12. stoljeća (Jurković 2016: 260).

Iz kratkog pregleda vidljivo je da se par konzola i nadvratnik s natpisom darovateljâ smatraju ranoromaničkim djelima, čija se datacija smješta krajem 11. ili početkom 12. stoljeća.

Stupanj tipološke i stilske srodnosti upućuje na to da se par konzola sa Svetog Mikule i konzola s kuće Mangjer mogu pripisati krugu iste radionice. S obzirom na spomenute razlike u izvedbenim kvalitetama, smatram da je prvo nastao par konzola sa Svetog Mikule. Njihova izvedba djelo je kvalitetne radionice, koja u splitsku sredinu donosi suvremena kiparska strujanja i stilizacije u Apuliji.

Majstor koji je izradio konzolu s kuće Mangjer dobro poznaje strukturu konzola sa Svetog Mikule, što potvrđuju gotovo identične dimenzije triju konzola, identična kompozicija elemenata na njima, postavka i sveukupni volumen lavlje figure. U

15 CD I, 109. Jakić-Cestarić mišljenja je da se završni čin koji se navodi u ispravi o osnutku samostana podjela imuniteta samostanu, dogodio znatno kasnije od 1068. godine, negdje između 1080. i 1085. Jakić-Cestarić 1980, 180-181.

16 U novijoj publikaciji crkvu datira u 11. st. i dalje, vidi Goss 2006: 229. 
izradi zahtjevnijih dijelova (lavlje glave, akantusova lista), on se pokazuje oblikovno slabijim. No, uklanjanje fonda između okvira konzole i lavlje figure, oblikovanje repa položenog na lavljim leđima, S profilacija na okviru konzole, izvedbeno su zahtjevniji od rješenja na konzolama sa Svetog Mikule. U interpretaciji predloška, majstorovo iskustvo utječe na izvedbu: lavlju glavu oblikuje poput mačje (osim na konzolama sa Svetog Mikule, vjerojatno druge izvedbe lavljih glava i nije vidio), dok se kod oblikovanja pramenova grive približava stilizaciji kuka na ranoromaničkim trabeacijama oltarnih ograda u gradu (poput kuka s oltarne ograde priora Firmina koja nastaje krajem 11. stoljeća i početkom 12. stoljeća). ${ }^{17}$ Stupanj sličnosti koji se otkriva u izvedbi akantusova lista na konzoli i listova na kapitelima u interijeru Svetog Mikule, mogao bi upućivati na to da je majstor sudjelovao u njihovoj izradi (pogotovo ako se prihvati da portal i gradnja crkve pripadaju istoj fazi). Slova imenice LEON slična su slovima natpisa na nadvratniku crkve, no njihova izvedba nije podjednako kvalitetna.

Majstor koji je izradio konzolu s kuće Mangjer pripada krugu radionice koja je izradila konzole Sv. Mikule. Bio je svakako manje kvalitetan kipar od glavnog majstora te radionice, navikao na izradu oblikovno manje zahtjevnih elemenata od prikaza životinjskih figura.

\section{Podrijetlo konzole}

Konzola je kao spolij bila ugrađena na istočnom zabatu kuće Mangjer (Slika 12). ${ }^{18}$ Kada je kuća sagrađena nije poznato, no ona je svakako starija od 1831. godine kada je u austrijskom katastru ucrtana na čestici pod anagrafskim brojem $1023 .{ }^{19} \mathrm{U}$ upisniku građevinskih čestica kao vlasnici navedeni su nasljednici trgovca Giovannija Mangera. ${ }^{20}$ Kuća je klasificirana kao casa d'abitar a due piani con corte. Budući da se na fotografiji njezina pročelja ne zamjećuju tragovi dogradnji, može se zaključiti da je konzola postavljena prilikom njezine gradnje. Sudeći prema stilskim odlikama, kuća je vjerojatno izgrađena krajem 18. stoljeća. U posjedu obitelji Mangjer kuća ostaje do 1917. godine. ${ }^{21}$ Nakon što je promijenila nekoliko vlasnika, kupoprodajnim ugovorom iz 1940. godine dolazi u posjed Splitske provincije Družbe sestara

17 Vidi Belamarić 1991; Delonga 1997: 11; Rapanić 1997. Slično se oblikovanje kuka nalazi i na zabatu oltarne ograde crkve svetog Petra na Lučcu datiranom u posljednju četvrtinu 11. stoljeća, Delonga 1997: 8-9; Piteša 2012: 74-77.

18 Ovom prigodom zahvaljujem sestri Zdravki Spomenki Milić i sestri Andrijani Ani Mirčeti (provincijalnoj poglavarici) na angažmanu i ustupljenim fotografijama iz samostanskog arhiva.

19 HR-DAST-152, AMID, Austrijski katastar, Protocolo delle particelle degli Edificj, K.O. Split - 595. U Alfabetičkom upisniku kuća obćine Spliet iz 1879. godine Matteo Manger naveden je kao vlasnik. Njegovo ime nalazi se i u Iskazu zemljišnih posjeda svih posjednika / Dimostrazione del posesso fondaritario del comune di Spalato iz 1883. U austrijskoj izmjeri iz 1910. godine vlasnik je dr. Giovanni Manger.

20 Obitelj Mangjer, čije se prezime u transkripciji javlja i kao Manger i Manđer, u Splitu se u dokumentima spominje od 1694. godine. Obitelj je naseljena u predgrađu Dobri (u kojem i danas postoji Manđerova ulica). vidi Kuzmanić 2008. Članovi obitelji: kanonik Petar Mangjer, dr. Ivan Mangjer (splitski gradonačelnik), Dušan Mangjer (prosvjetar, publicist i knjižničar) imali su važnu ulogu u kulturnom i javnom životu grada Splita tijekom 19. i 20. stoljeća.

21 Zemljišnoknjižni odjel Split, Izvadak iz Zemljišne knjige, Broj ZK uloška: 936, Povijesni prikaz vlastovnice Upis B, 471. 
milosrdnica sv. Vinka Paulskog u Splitu. ${ }^{22}$ Kuća je porušena radi izgradnje novoga samostanskoga kompleksa sredinom devedesetih godina prošlog stoljeća.

Nije moguće utvrditi izvorni arhitektonski kontekst konzole. U razgovoru $s$ gospođom Maricom Rismondo Berket i gospodinom Mihovilom Rismondom, potomcima obitelji Mangjer, doznaje se da u obitelji nije bila sačuvana predaja kada je konzola donesena niti s kojeg je lokaliteta. ${ }^{23}$ Konzola je vjerojatno u paru flankirala ulaz neke crkve sagrađene ili obnovljene u ranoromaničkom stilu. Ta se intervencija zbila nakon izrade konzola sa Svetog Mikule (vjerojatno oko početka 12. stoljeća). Nažalost, nije moguće odrediti o kojoj je crkvi riječ. Zbog relativno malih dimenzija i težine od tridesetak kilograma, konzolu je bez većih napora bilo moguće donijeti s bilo kojeg lokaliteta u gradu ili na poluotoku.

Ipak, zbog udaljenosti od oko 100 metara zračne linije od kuće Mangjer, valja spomenuti lokalitet ad basilicas pictas i crkvu svetog Andrije, koja se spominje na tom lokalitetu u darovnici iz 1119. godine (CD, II, 33), u kojoj je 1185. održala sinoda splitske crkve (CD II. ${ }^{24}$ Prema usmenoj predaji, koju je zabilježio D. Maršić obrađujući spolije na kući u Vukasovićevoj ulici na Manušu, stanovnici Manuša za gradnju kuća s tog su lokaliteta uzimali građevni materijal (Maršić 1995: 26).

Zanimljivo jest i da je šira obitelj Mangjer u svojstvu kolona obrađivala parcele na dvama lokalitetima: na Brniku (gdje u blizini nema ostataka crkava, niti toponima koji bi upućivali na njihovo postojanje) i na Sukoišanu (čestica se nalazila na račvanju Ulice Ante Starčevića iznad današnje Školske poliklinike). ${ }^{25}$ Premda se predio naziva po crkvi svetog Kasijana, crkva do sada ipak nije ubicirana. ${ }^{26}$

\section{Ikonografska analiza}

Lav u arhitektonskoj skulpturi predstavlja jednu od najučestalije prikazivanih figura romaničkog bestijarija u europskoj i u splitskoj baštini. ${ }^{27}$

Srednjovjekovna misao uz lava i njegovu prirodu vezuje dvojakost značenja. $\mathrm{Na}$ pravcima koje je trasiralo ranokršćanstvo, srednjovjekovna egzegeza, tu životinju s jedne strane uzdiže na razinu kristološkog simbola par excellence, dok s druge, ona može biti sotonskim amblemom (Charbonneau-Lassay 2006: 35-53). Tijekom romaničkog razdoblja često se pored prikaza lavljeg lika ispisuju verseti kako bi potvrdili značenje u kojem se figura upotrebljava (Favrault 1991).

Kristološka simbolika razvija se na latinskim prijevodima grčkog Physiologusa

22 Zemljišnoknjižni odjel Split, Izvadak iz Zemljišne knjige, Broj ZK uloška: 936, Povijesni prikaz vlastovnice Upis B, 472.

23 Gospođi Rismondo Berket i gospodinu Rismondo od srca zahvaljujem na odvojenom vremenu i svesrdnoj pomoći.

240 problematici titulara i sakronima koji se vezuju za lokalitet ad basilias pictas, Buškariol 1987; Buškariol 1990; Marasović 2011: 397-400.

25 Austrijski katastar, Terreni Comune Censuario di Spalato, 1831. godine.

26 Buškariol 1984: 81. Don Frane Bulić zabilježio je predaju o ostatcima crkve svetog Kasijana pronađene tijekom gradnje vile Bulat koja se nalazi jugozapadno od lokaliteta ad basiclias pictas.

27 Tijekom 12. i 13. stoljeća u obliku lavlje glave izrađena je konzola u Dioklecijanovoj ulici, vodorige na hotelu Central i na luku u Bajamontijevoj ulici (Fisković 1940, Fisković 1952); lavlje protome nalaze se na zvoniku katedrale (u dvjema varijantama: tri protome kandžama drže svitak, a jedna njima drži plijen); lavovi-stilofori flankiraju prolaz koji vodi kroz zvonik u katedralu (Jelić 1895; Kečkemet 1955; Babić 2007). 
(Zucker 2005: 28-31), na osnovi triju svojstava koje lavu pridaje Physiologus: lav uvijek spava otvorenih očiju i njegova budnost ni tada ne popušta; lav pošteđuje život onima koje je pobijedio u borbi; lavica rađa mrtvi porod kojemu otac nakon tri dana udahnjuje život. ${ }^{28}$

Simboličko značenje koje nosi pojedina lavlja figura (u našem slučaju skulptura), u romanici se otkriva preko njezina oblikovanja (naglašenost pojedinih dijelova tijela) i konteksta u koji se figura smješta.

Na našim konzolama lavlje su figure prikazane širom otvorenih očiju, u položaju koji insinuira spremnost životinje na djelovanje (u čučnju, prednjim nogama uprtim o pulvin konzole). Takav se prikaz odnosi na Kristovu vječitu budnost i pripravnost da djeluje i zaštiti kršćanske duše. Apotropejsko svojstvo naglašeno je i oblikovanjem njuške s iskešenim očnjacima. Kod oblikovanja tijela naglasak je stavljen na prednji dio (glava, prednje noge i izrazito naglašen volumen grudnoga koša), dok su stražnje noge nerazmjerno manje. Takva forma tijela alegorijski predstavlja dvojakost Kristove prirode: prednji, u obradi naglašeniji dio tijela, odnosi se na njegovu (Kristovu) božansku prirodu, dok se stražnji, manje razvijen, odnosi na ljudsku. ${ }^{29}$

Pozicija konzola na portalu Svetog Mikule zaokružuje simbolički sadržaj. U topografskoj simbolici crkvenog zdanja, ulaz u crkvu, osim što fizički predstavlja i granicu između profanog i sakralnog, simbolizira i granicu između zemaljskoga i nebeskoga, put kojim se preko Kristove žrtve otvara pristup nebeskom Jeruzalemu i Spasenju. Uz navedeno, ulaz se vezuje i uz poimanje Kristove i kršćanske pravednosti. ${ }^{30}$

U kontekstu privatne zavjetne crkve koju gradi Messagalina, lavovi na portalu imaju apotropejsku funkciju - simboliziraju Krista koji bdije nad zadužbinom i obitelji Messagalina, preko kojeg se otvara put spasenju njihovih duša. Moglo bi se reći da konzole s natpisom na nadvratniku predstavljaju svojevrsnu vizualnu zagovornu formulaciju. U tom pogledu valja sagledati i natpis LEON na konzoli s kuće Mangjer koji je ispisan da bi potvrdio identitet lava - kristološkog amblema.

\section{Zaključak}

Ranoromanička radionica koja izrađuje konzole sa Svetog Mikule (čijem krugu pripada i majstor konzole s kuće Mangjer), donosi prvi prodor romaničke skulpture visokoga, gotovo ronde-bosse, plasticiteta u lokalnu splitsku sredinu. Riječ je o radionici koja je upoznata sa suvremenim zbivanjima na Apeninskom poluotoku i predlošcima koji se razrađuju, kako smo zasad uspjeli utvrditi, na području Apulije.

280 razvitku srednjovjekovne kristološke simbolike na osnovi različitih verzija Phyiologosa, Favreau 1991: 622-628.

29 Sveti Irenej alegorijski povezuje prednji dio lavljeg tijela s nebeskim, a stražnji sa zemaljskim. Nekoliko decenija nakon nastanka splitskih konzola, Phillipe de Taun će u Bestijariju produbiti tu alegoriju. Prema njegovu tekstu Božanska snaga nastanjuje lavlje grudi, dok Njegova Ljudskost obitava u slabijem, stražnjem dijelu, Charbonneau Lassay 2006: 40.

30 Simbolika je razvijena na temelju biblijskih verseta: Iv, 10,9: „Ja sam vrata. Tko uđe kroza me, bit će spašen; on će ulaziti i izlaziti i pašu nalaziti“; Iv, 14, 6: „Ja sam Put, i Istina, i Život - odgovori mu Isus - Nitko ne dolazi Ocu osim po meni.“; Otkrivenje 3, 19-20: „Evo, stojim pred vratima i kucam. Ako tko posluša moj glas i otvori vrata, ući ću k njemu i večerati s njime, i on sa mnom.“; Ps, 118 (117), 19-20: „Otvorite mi širom vrata pravde: ući ću, Jahvi zahvalit! Ovo su vrata Jahvina, na njih ulaze pravedni!“ Citate srednjovjekovnih teologa-simbolista vezane uz značenje portala donosi Götz 1971: 9-31. 
Aktivnost radionice koju na ovom stupnju spoznaja možemo okvirno smjestiti u posljednji decenij 11. i početak 12. stoljeća, odvija se u razdoblju snažnog prosperiteta grada i njegova jačanja kao političkoga, crkvenoga i kulturnog središta, koje započinje šezdesetih godina 11. stoljeća. Nakon Bizanta, grad priznaje vlast hrvatskih kraljeva Petra Krešimira IV. i Zvonimira. Nadbiskup Lovre dolazi na čelo splitske crkve, gorljivi je provoditelj smjernica crkvene reforme za čijeg se episkopata (1059 - 1099. godine) bilježi kulturni i graditeljski zamah grada. Lovre je promotor novih ideja te se uz njegovo posredno ili neposredno djelovanje mogu vezati i prvi prodori romaničkog stila. ${ }^{31}$

Graditeljski pothvat obitelji Messagalina predstavlja tek jedan u nizu pothvata koje tada, bilo na gradnji bilo na obnovi crkvenih zdanja, poduzimaju pripadnici splitskog patricijata. Zavjetnu obiteljsku crkvu ukrašavaju mramornim spolijima, što pokazuje ugled i moć koju su Messagaline imali u gradu. Patricij Johannes i sestra mu Nemira poznaju nadbiskupa (Johannes se javlja kao svjedok u fundacijskoj ispravi kojom Lovro osniva samostan sv. Benedikta, a Nemira samostanu daruje crkvu), upoznati su s njegovom misijom, stavovima, vjerojatno preko njega saznaju i o novim strujanjima i zadatcima likovnosti koje donosi reforma. Premda se tipološki njihova crkva nastavlja na predromaničku tradiciju, konzole na njezinu pročelju svjedoče o priklanjanju novim idejama.

U razvitku romaničke skulpture u Splitu, ove konzole predstavljaju međaš označavaju početak nove etape koja će se odvijati tijekom 12. stojeća, u kojoj se razvija arhitektonska skulptura visokog plasticiteta.

Nažalost, budući da većina tog opusa skulpture te etape predstavlja spolije, ugrađene na kasnijim zdanjima u povijesnoj jezgri, ${ }^{32}$ nepoznavanje njihova izvornoga arhitektonskoga konteksta uvelike otežava istraživanje.

Već pri prvom pokušaju sistematizacije dosadašnjih spoznaja i utvrđivanja osnovnih etapa razvitka tijekom 12. i 13. stoljeća, uočavaju se određene nelogičnosti u vidu „produkcijskih pauza“ i „stilsko-razvojnih nelogičnosti i/ili nedosljednosti“. Produkcijske pauze odgovaraju razdobljima tijekom kojih, prema današnjem stupnju spoznaja, nema datiranih elemenata, dok se pod "stilskim nelogičnostima“ podrazumijeva očita stilska retardacija kod pojedinih djela pripisanih 13. stoljeću, koja su poslužila za datiranje skulptura srodnih stilskih odlika.

Problematika je dodatno otežana nemogućnošću odjeljivanja graditeljskih faza najreprezentativnijega romaničkog pothvata u gradu - zvonika katedrale. Njegova gotovo faksimilna obnova krajem XIX. stoljeća, onemogućila je prepoznavanje slijeda graditeljskih intervencija i njihovih datacija. Donedavno rasprostranjeno mišljenje, koje je ukotvilo početak njegove gradnje oko polovice 13. stoljeća i predstavljalo terminus post quem datacije svih romaničkih skulptura na zvoniku, unijelo je dodatnu zbrku. ${ }^{33}$

Nove teze gradnju prvog zvonika smještaju u predromaničko doba. ${ }^{34}$ Slijedom

310 ulozi nadbiskupa Lovre u kulturnom procvatu grada i graditeljskim pothvatima u doba njegova episkopata, Delonga 1997: 3-6; Jurković 2016.

32 Vidi fusnotu br. 3.

33 O fazama gradnje zvonika vidi Jelić 1895, Babić 2007 donosi pregled.

34 Gradnja prvoga predromaničkog zvonika prema Miloševiću odvija se u 8. stoljeću, Milošević, Peković 2009: 158-163; Milošević 2011: 101-102, sl. 105. Marasović 2011, 266-267, sl. 352, objavljuje 
kasnijih faza gradnje istraživanja se još nisu pozabavila. Nužna je stilska i datacijska revalorizacija skulptura sa zvonika. Naime, neka djela poput protoma lavova i sfingi koje se danas nalaze na 3. i 4. katu, mogla bi prema formalno-stilskim karakteristikama odgovarati opusu 12. stoljeća. Ako je tomu tako, vjerojatno su tijekom gradnje viših katova one bile premještene s nižih na te pozicije.

Grupiranje djela koja pripadaju određenoj romaničkoj sekvenciji razvitka, kao i eventualno objedinjavanje djela do sada neprepoznatih radionica, zadaća je koja tek treba uslijediti.

\section{Literatura}

Babić, I. 2007. „Zapažanja o zvoniku splitske katedrale“. Vjesnik za arheologiju u povijest dalmatinsku,100, 145-200.

Babić, I. 2010. „O reljefu s prikazom kralja iz Splitske krstionice“. Archaeologia Adriatica, IV, 203-215.

Barada, M. 1952. „Notae epigraphicae“. Starohrvatska prosvjeta, III, 2, 179-182.

Barall i Altet, X. 2015. „Art monumental roman et réforme grégorienne: plaidoyer contre une fiction historique très enracinnée". U Barbara Franzé (ur.), Art et réforme grégorienne, $X I^{e}-X I{ }^{e}$ siècles, en France et dans la péninsule Ibérique (str. 41-56). Paris: Éditions A. et J. Picard.

Belamarić, J. 1990. „Romaničko kiparstvo“. U Igor Fisković (ur.), Tisuću godina hrvatskog kiparstva (str. 41-75). Zagreb: Muzejsko galerijski centar.

Belamarić, J. 1991. Gospe od zvonika u Splitu. Zagreb: Društvo konzervatora Hrvatske.

Belamarić, J. 2001. Studije iz srednjovjekovne i renesanse umjetnosti na Jadranu. Split: Književni krug.

Belli d'Elia, P. 1987. Alle sorgenti del romanico. Puglia XI secolo. Bari: Edizioni Dedalo.

Belli d'Elia, P. 2003. Puglia Romanica. Brescia: Jaca Book.

Burić, T. 1992. „Jedna splitska ranoromanička radionica iz treće četvrtine 11. stoljeća“. Prilozi povijesti umjetnosti u Dalmaciji, 32, 207-219.

Burić, T. 2002. „Pluteji oplate splitske krstionice - vrijeme i okolnosti postanka“. U Ivo Babić, Ante Milošević, Željko Rapanić (ur.), Zbornik Tomislava Marasovića (str. 302-327). Split: Sveučilište u Splitu, Muzej hrvatskih arheoloških spomenika.

Buškariol, F. 1984. „Prilozi arheološkoj topografiji Manuša“. Kulturna baština, 15, 75-86.

Buškariol, F. 1987. „Marginalija uz crkvu svetog Andrije“. Kulturna baština, 17, 32-44. Buškariol, F. 1990. „De ecllesiis pictis“. Starohrvatska prosvjeta, III, 20, 289-300.

Charbonneau Lassay, L. 2006. Le bestiaire du Christ, Paris: Albin Michel.

Codex Diplomaticus Regni Croatiae, Dalmatiae et Slavoniae, I, Zagreb 1967.

Delonga, V. 1997. Romanički natpisi grada Splita. Split: Muzej hrvatskih arheoloških spomenika.

Favreau, R. 1991. „Le theme iconographique du lion dans les inscriptions médiévales“, Académie des Inscriptions et Belles-Lettres, Comptes rendus des séances de l'année 1991, 613-636.

pretpostavljeni izgled predromaničkog zvonika prema Jerku i Katji Marasović. Valja napomenuti da je Jerko Marasović izradio idejnu rekonstrukciju izgleda romaničkog zvonika vremena oko polovice 12. stoljeća koja, nažalost, još nije objavljena. 
Fisković, C. 1940. „Nekoliko neobjelodanjenih romaničkih skulptura u Splitu“. Serta Hoffileriana, 443-452.

Fisković, C. 1949. „Istraživanja u srednjovjekovnoj crkvi svetog Nikole u Splitu“. Historijski zbornik 1-4, 211-220.

Fisković, C. 1952. „Romaničke kuće u Splitu i Trogiru“. Starohrvatska prosvjeta, III, 2, 129-178.

Fisković, C. 1979. „Prilog za romaniku u Hvaru“. Zbornik Narodnog muzeja u Beogradu, IX-X, 301-306.

Fisković, C. 1981. „U tragu za splitskom romanikom“. Bulletin razreda za likovne umjetnosti JAZU , 2 (50), 81-106.

Fisković, I. 2000. „Kiparstvo“. U E. Hercigonja (ur.), Hrvatska i Europa, kultura, znanost, umjetnost, Svezak II. Srednji vijek i renesansa (XIII-XVI. stoljeće) (str. 641-661). Zagreb: Školska knjiga.

Fisković, I. 2002. Reljef kralja Petra Krešimira IV. Split: Muzej hrvatskih arheoloških spomenika.

Flèche Mourgues, M.-P.; Chevalier, P.; Piteša, A. 1993. "Catalogue de sculpture du Haut Moyen âge du Musée Archéologique de Split". Vjesnik za arheologiju i historiju dalmatinsku, 85, 207-305.

Franzé, B. 2015. Art et réforme grégorienne, $X I^{e}-X I I^{e}$ siècles, en France et dans la péninsule Ibérique. Paris: Éditions A. et J. Picard.

Goss, V. P. 1987. Early Croatian Architecture. London, Duckworth.

Goss, V. P. 2006. Predromanička arhitektura u Hrvatskoj / Pre-romanesque architecture in Croatia. Zagreb: Art studio Anzinović.

Goss, V. P. 2012. „The $11^{\text {th }}$ Century Reform and the Visual Arts. The Eastern Adriatic Test Case". U Glauco Maria Cantarella, Arturo Calzona (ur.), La Reliquia del Sangue di Cristo. Mantova, l'Italia e l'Europa al tempo di Leone IX (str. 573590). Trento: Scripta Edizioni.

Götz, U. 1971. Die Bildprogramme der Kirchentüren des 11. und 12. Jahrhunderts. Doktorska disertacija. Tübingen.

Ilić Olujić, T. 2007. „Le portail à tympan de l’église Saint-Pierre de Supetarska Draga sur l'île de Rab“. Hortus artium medievalium, 13, 457-464.

Jakić-Castarić, V. 1980. „O donatorima crkve svetog Nikole u Velom Varošu u Splitu i o crkvama tog sveca u splitskim izvorima XI i XII stoljeća“. Prilozi povijesti umjetnosti u Dalmaciji, 21, 1, 174-189.

Jelić, L. 1895. „Zvonik spljetske stolne crkve“. Viestnik Hrvatskoga arheološkoga društva, 1, 29-95.

Jurković, M. 1992. „Crkvena reforma i rano romanička arhitektura na istočnom Jadranu“. Starohrvatska prosvjeta, 20, 191-213.

Jurković, M. 1996. „Pojava romaničke arhitekture u Hrvatskoj“. U Miljenko Jurković, Tugomir Lukšić (ur.), Starohrvatska spomenička baština. Rađanje prvog hrvatskog kulturnog pejzaža (str. 325-338). Zagreb: Muzejsko-galerijski centar, Odsjek za povijest umjetnosti Filozofskog fakulteta Sveučilišta, Nakladni zavod Matice hrvatske.

Jurković, M. 2016. „Un abbé et un archevêque - protagonistes de la Réforme de l'Église dans la Croatie du XI ${ }^{\mathrm{e}}$ siècle“. U David Moret, Sébastien Frey (ur.), Évêques et abbés à l'époque romane. Texte, munuments images et objets (str. 
253-268). Aurillac: Éditions Abedia.

Kautzsch, R. 1936. Kapitellstudien. Beiträge zu einer Geschichte des spätantiker Kapitells im Osten vom vierten bin ins siebten Jahrhundert. Berlin, Leipzig: Verlag von Walter de Gruyter \& Co.

Kečkemet, D. 1955. „Figuralna skulptura s romaničkog zvonika splitske katedrale“. Prilozi povijesti umjetnosti u Dalmaciji, 9, 91-135.

Kuzmanić, N. 2008. Splićani - obitelji i prezimena. Split: Magistra.

Marasović, T. 1994. Graditeljstvo starohrvatskog doba u Dalmaciji. Split: Književni krug Split.

Marasović, T. 2011. Dalmatia praeromanica: ranosrednjovjekovno graditeljstvo u Dalmaciji. 3. korpus arhitekture Srednja Dalmacija. Split - Zagreb: Književni krug Split, Muzej hrvatskih arheoloških spomenika u Splitu, Arhitektonski fakultet Sveučilišta u Zagrebu.

Maršić, D. 1995. „Tri ulomka kamene plastike iz Vukasovićeve ulice - prilog poznavanju sakralnog kompleksa Basilicae Pictae (Sv. Andrija)“. Kulturna baština, 19, 23-28.

Matetić Poljak, D. 2017. „Roman and late antique spolia in the city of Trogir (Croatia)“.U Patrizio Pensabene, Marina Milella, Fancesca Caprioli (ur.), Decor. Decorazione e Architettura nel Mondo romano. Atti del Convegno Internazionale, Roma, 2124 maggio 2014, Thiasos monografie, 9. Roma: Edizioni Quasar.

Milošević, A.; Peković, Ž. 2009. Predromanička crkva Svetoga Spasa u Cetini. Dubrovnik - Split: Omega engineering d. o. o. Dubrovnik, Centar Studia Mediterranea Split.

Milošević, A. 2011. Predromanički zvonici u Dalmaciji i ranosrednjovjekovnoj Hrvatskoj. Dubrovnik - Split: Omega engineering d. o. o. Dubrovnik, Studia Mediterranea - Filozofski Fakultet u Splitu.

Quintavalle, A. C. 2015. „La réforme grégorienne: image et politique $\left(\mathrm{XI}^{\mathrm{e}}-\mathrm{XII}{ }^{\mathrm{e}}\right.$ siècles)“. U Barbara Franzé (ur.), Art et réforme grégorienne, $X I^{e}-X I{ }^{e}$ siècles, en France et dans la péninsule Ibérique (str. 15-40). Paris: Éditions A. et J. Picard.

Pensabene, P. 1993. Elementi architettonici di Alessandria e di altri siti egiziani. Roma: „L'Erma“ di Bretschneider.

Pensabene, P. 2015. Roma su Roma. Reimpiego archtettonico, recupero dell'antico e trasformazioni urbani tra il III e il XIII secolo. Monumenti di antichità christiana, ser. II, vol XXII. Città del Vaticano: PIAC.

Petricioli, I. 1960. Pojava romaničke skulpture u Dalmaciji. Zagreb: Društvo historičara umjetnosti Hrvatske.

Petricioli, I. 1983. Tragom srednjovjekovnih umjetnika. Zagreb: Društvo historičara umjetnosti Hrvatske.

Petricioli, I. 1993. „Na tragu klesarske radionice iz 11. stoljeća“. Vjesnik za arheologiju i historiju dalmatinsku, 86, 287-292.

Piteša A. 2007. Split u Arheološkom muzeju. Split: Arheološki muzej u Splitu.

Piteša, A. 2012. Ranosrednjovjekovni kameni spomenici u Arheološkome muzeju u Splitu. Split: Arheološki muzej u Splitu.

Prijatelj, K. 1954. „Skulpture s ljudskim likom iz starohrvatskog doba“. Starohrvatska prosvjeta, IIl/3, 65-91. 
Rapanić, Ž. 1997. „Oltarna ograda splitskog priora Furmina“. Prilozi povijesti umjetnosti u Dalmaciji, 35, 327-344.

Russo, D. 2008. „La réforme de l'Église et le moment figuratif dans l'art religieux ( $\mathrm{XI}^{\mathrm{e}}$ $\mathrm{XII}^{\mathrm{e}}$ siècles)“. Bulletin du centre d'études médiévales d'Auxerre / BUCEMA [En ligne], Hors-série $n^{\circ} 2$ |2008, mis en ligne le 15 janvier 2009, consulté le 10 mars 2019. URL : http://journals.openedition.org/cem/9182.

Rutar S.; Bulić F.; Jelić L. 1984. Guida di Spalato e Salona. Zara: Stabilimento tipografico di S. Artale.

Zucker, A. (ur.) 2005. Physiologos: Le Bestiarie des Bestiaires, Texte traduit du grec, établi et commenté par Arnauld Zucker. Grenoble: Éditon Jérôme Million.

\section{Arhivski izvori}

HR-DAST-152, Arhiv mapa za Istru i Dalmaciju, Austrijski katastar, Protocolo delle particelle degli Edificj (Copia), K.O. Split - 595

Zemljišnoknjižni odjel Split, Izvadak iz Zemljišne knjige, Broj ZK uloška: 936.

\section{Prilozi}

Slika 1. Konzola s prikazom lava s kuće Mangjer, desna bočna strana (fotografija: D. Matetić Poljak)

Slika 2. Konzola s prikazom lava s kuće Mangjer, prednja strana (fotografija: D. Matetić Poljak)

Slika 3. Konzola s prikazom lava s kuće Mangjer, lijeva bočna strana (fotografija: D. Matetić Poljak)

Slika 4. a) Akantusov list, konzola s kuće Mangjer; b) akantusov list, konzola s portala

Svetog Mikule (fotografija: D. Matetić Poljak)

Slika 5. Portal Svetog Mikule (fotografija: D. Matetić Poljak)

Slika 6. Konzola s portala Svetog Mikule, lijeva bočna strana (fotografija: D. Matetić Poljak)

Slika 7. Konzola s portala Svetog Mikule, prednja strana (fotografija: D. Matetić Poljak)

Slika 8. Konzola s portala Svetog Mikule, desna bočna strana (fotografija: D. Matetić Poljak)

Slika 9. Kapitel iz Svetog Mikule (fotografija: autor nepoznat, Fototeka Konzervatorskog odjela u Splitu, Inv. Br. 132704)

Slika10.BaroknopročeljeSvetog Mikule(fotografija: D. Stuhler,Fototeka Konzervatorskog odjela u Splitu, Inv. Br. 2786)

Slika 11. Konzola na baroknom pročelju Svetog Mikule (fotografija: D. Stuhler, Fototeka Konzervatorskog odjela u Splitu, Inv. Br. 2718)

Slika 12. Kuća Mangjer s konzolom na zabatu (fotografija: autor nepoznat, Arhiv Samostana sestara milosrdnica sv. Vinka Paulskog u Splitu) 


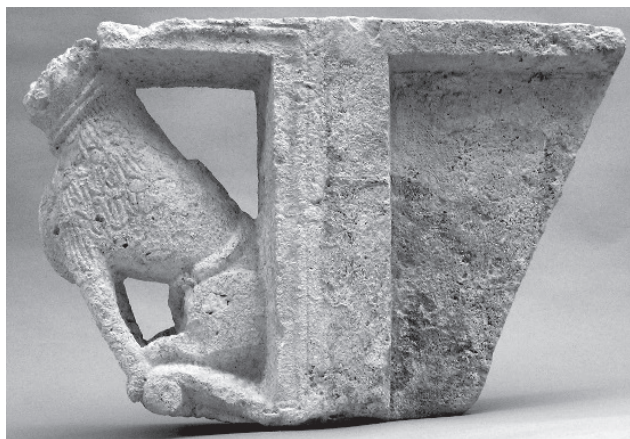

Slika 1.

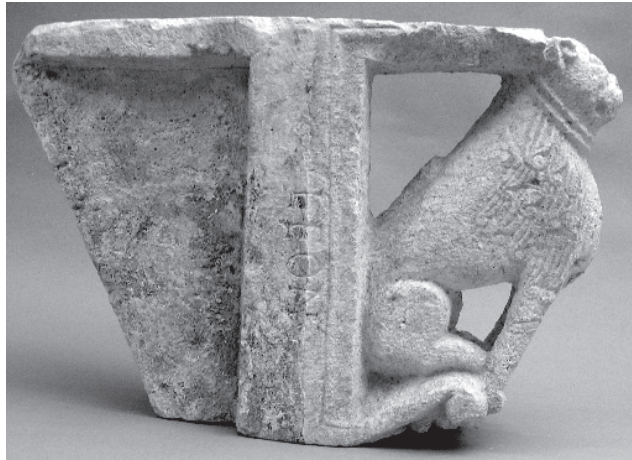

Slika 3.

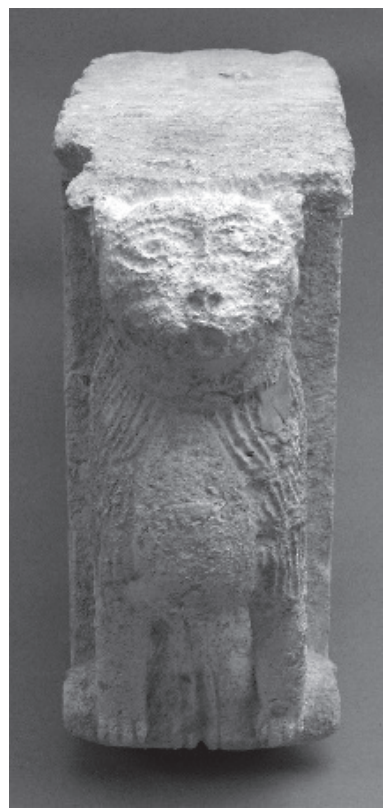

Slika 2.

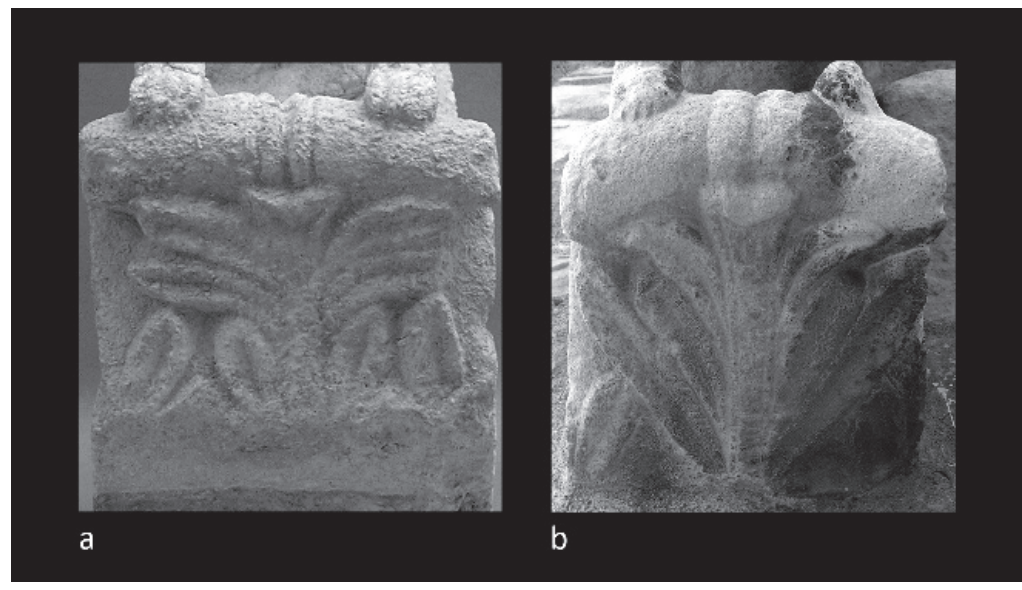

Slika 4. a) i b) 


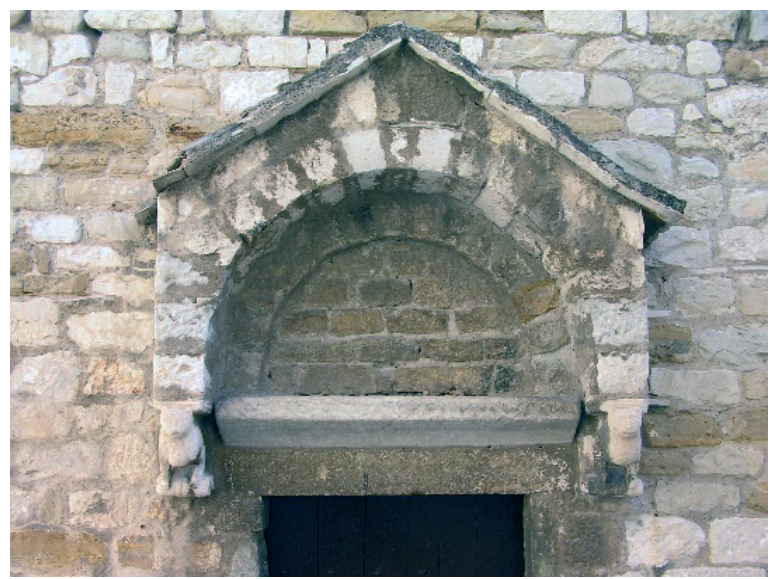

Slika 5.

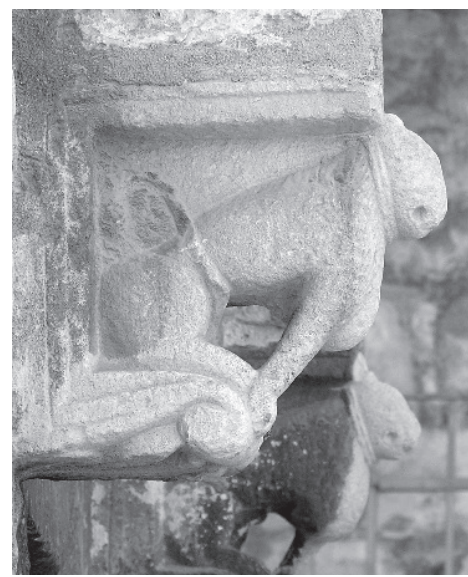

Slika 6.

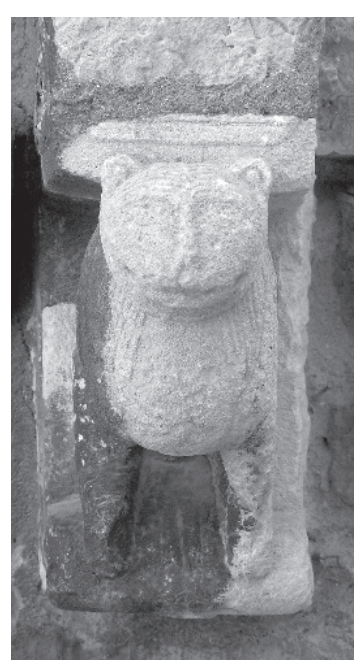

Slika 7.

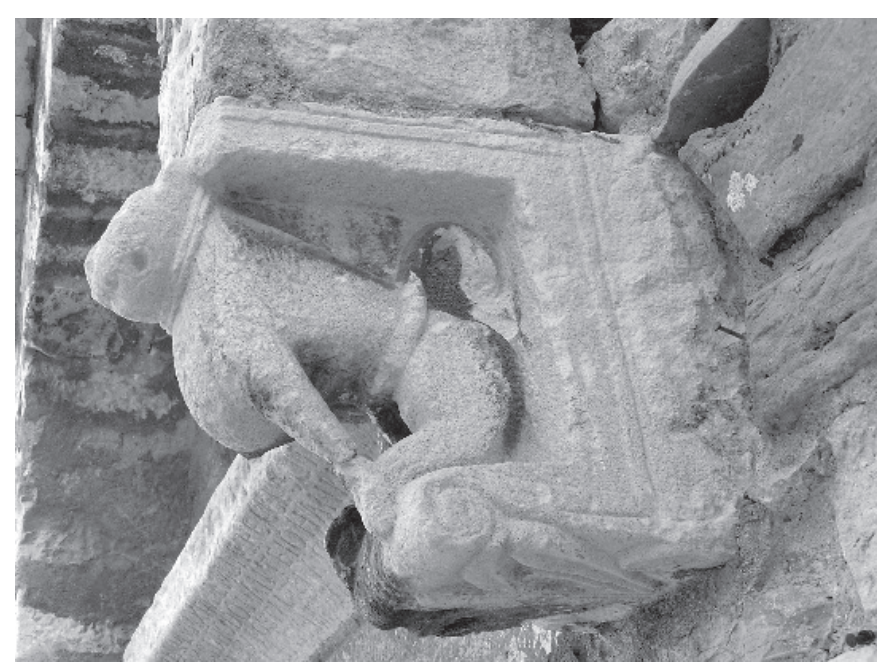

Slika 8. 


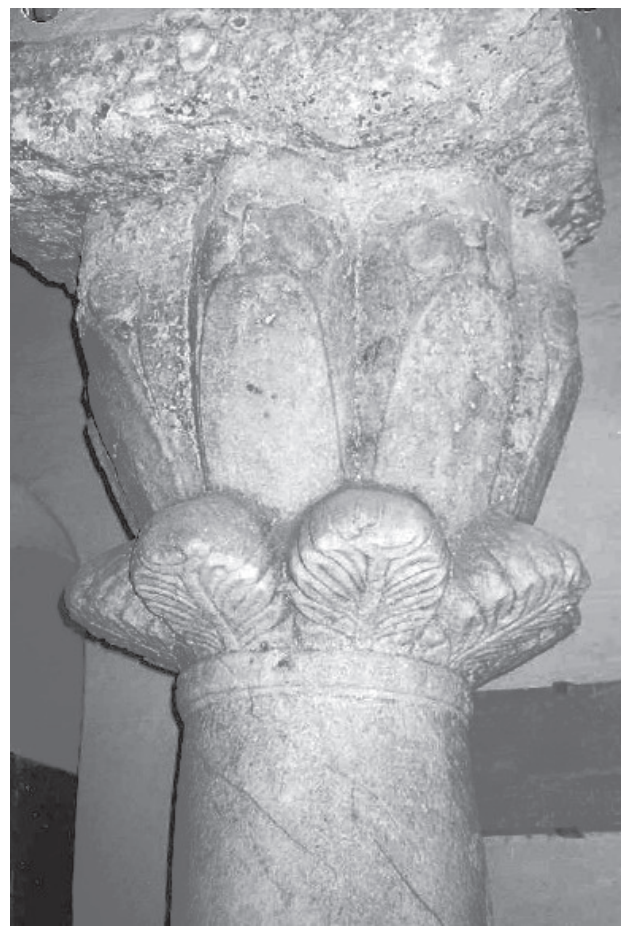

Slika 9.

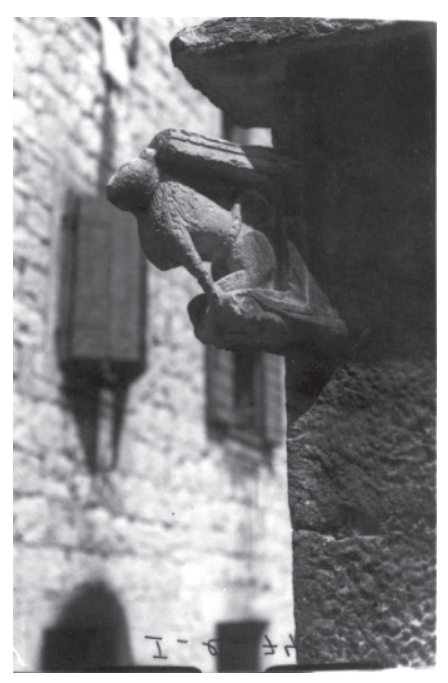

Slika 11.

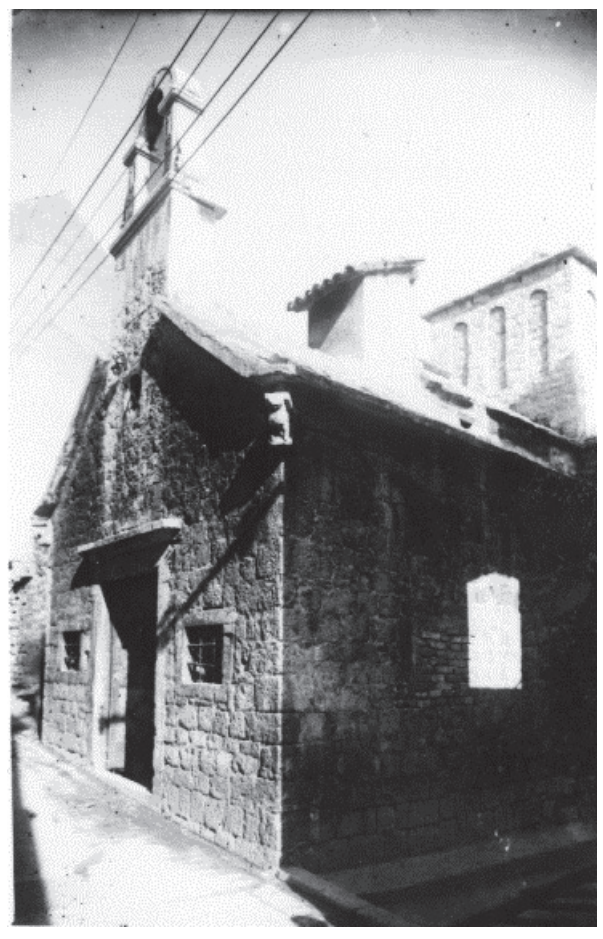

Slika 10.

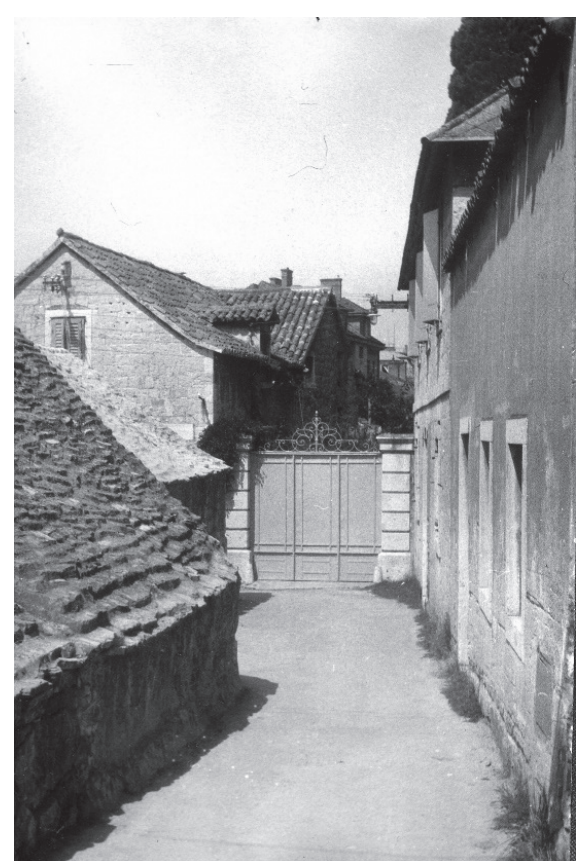

Slika 12. 


\title{
A CONTRIBUTION TO AN EARLY ROMANESQUE SCULPTUE WORKSHOP IN SPLIT
}

\begin{abstract}
In this paper, the stylistic and iconographic analysis of a console with a depiction of a lion, which was installed as spolia on the gable of the Mangjer house in Split, was performed. The house was situated at the intersection of Manđerova Street and Bribirska Street. After its demolition, the console was transferred to the Monastery of the Sisters of Charity of St. Vincent de Paul in Split, where it is still kept today. The original architectural context of the console is unknown. In terms of type and style, this console is similar to a couple of consoles on the portal of the Church of St. Mikula (St. Nicholas) in Veli Varoš, Split. The author groups them within the same early Romanesque workshop circle which operated in the late $11^{\text {th }}$ and early $12^{\text {th }}$ centuries. The console from the Mangjer house was created shortly after the abovementioned consoles from Saint Mikula. It was made by a master craftsman who had good knowledge of the latter consoles, skilfully copying their composition and dimensions. The design of more complex parts (such as the lion's head or the acanthus leaf on a small console under the lion's figure), when compared to the original template, reveals a lesser design capacity.
\end{abstract}

Key words: Architectural Sculpture, Early Romanesque Workshop, Split, Lion, Iconography 